\title{
PENERAPAN PENDEKATAN PROBLEM BASED LEARNING UNTUK MENINGKATKAN KEMAMPUAN PEMECAHAN MASALAH MATEMATIS SISWA KELAS VII MTs PADA MATERI PERBANDINGAN DAN SKALA
}

\author{
Ratna Marlina ${ }^{1}$, Sifa Nurjahidah ${ }^{2}$, Asep Ikin Sugandi ${ }^{3}$, Wahyu Setiawan ${ }^{4}$ \\ 1,2,3,4 IKIP Siliwangi Bandung, J1. Terusan Jenderal Sudirman, Cimahi, Jawa Barat, Indonesia \\ ${ }^{1}$ ratnamarlina35@gmail.com, 2sifanurjahidahdarochmat@gmail.com, \\ 3asepikinsugandi@ikipsiliwangi.ac.idgmail.com, ${ }^{4}$ kakwahyu3@gmail.com
}

Diterima: 10 Maret 2018;Disetujui: 28 Mei 2018

\begin{abstract}
This research aims to get results description of application of problem based learning approach in an effort to enhance student learning outcomes as well as knowing the increase in mathematical problem solving ability grade VII MTs on comparison of material and scale. The methods used in this research in the research conducted through two cycles of activity, and each cycles as much as 2 meeting. The subjek of this research is the teacher and all students of classes VII-B of 30 people. The object of this research are mathematical problem solving ability of students and the analysis undertaken aiming to find out the types of difficulties, hardships, cause factors and how the students in difficulty against handling problem solving math.
\end{abstract}

Keywords: PBL, problem-solving ability, comparison and scale

\begin{abstract}
Abstrak
Penelitian ini bertujuan untuk memperoleh hasil deskripsi tentang penerapan pendekatan Problem Based Learning dalam upaya meningkatkan hasil belajar siswa serta mengetahui peningkatan dalam kemampuan pemecahan masalah matematika siswa kelas VII MTs pada materi perbandingan dan skala.Metode yang digunakan dalam penelitian ini adalah Penelitian Tindakan Kelas (PTK) atau Classroom Action Research yang dilakukan melalui dua siklus kegiatan, dan setiap siklus sebanyak 2 pertemuan.Subjek dalam penelitian ini adalah guru dan seluruh siswa kelas VII-B yang berjumlah 30 orang.Objek dari penelitian ini adalah kemampuan pemecahan masalah matematis siswa dan analisis yang dilakukan bertujuan untuk mengetahui jenis-jenis kesulitan, faktor penyebab kesulitan, dan bagaimana penanganan terhadap kesulitan siswa dalam pemecahan masalah matematika.

Kata Kunci: PBL, Kemampuan Pemecahan Masalah, Perbandingan dan Skala
\end{abstract}

How to cite: Marlina, R., Nurjahidah, S., Sugandi, A. I., \& Setiawan, W. (2018). Penerapan Pendekatan Problem Based Learning untuk Meningkatkan Kemampuan Pemecahan Masalah Matematis Siswa Kelas VII MTs pada Materi Perbandingan dan Skala. JPMI - Jurnal Pembelajaran Matematika Inovatif, 1 (2), 93-218.

\section{PENDAHULUAN}

Matematika merupakan perkembangan teknologi dasar modern. Banyak siswa menganggap tujuan matematika hanya agar dapat berhitung saja ternyata lebih dari itu, matematika diajarkan pada dasarnya supaya siswa mampu menghadapi berbagai permasalahan di kehidupan ini dan juga pembelajaran matematika dituntut suatu kajian pengetahuan yang sangat tinggi, sehingga apabila siswa paham konsep dasar matematika maka dapat diterapkan 
dalam kehidupan sehari-hari. Oleh karena itu, matematika sangat penting dan dipelajari pada tiap jenjang pendidikan, hal ini ditegaskan oleh Cockroft (Setiawan, 2015)mengemukakan alasan bahwa perlunya matematika diajarkan kepada siswa, karena (1) digunakan dalam bidang kehidupan, (2) diperlukan kesesuaian keterampilan matematika untuk semua bidang, (3) diperlukan sarana koneksi yang singkat, kuat, dan jelas, (4) mengemukakan data dalam berbagai model (5) menumbuh-kembangkan cara berfikir logis, dan sifat teliti (6) rasa puas jika dapat menyelesaikan masalah. Untuk memahami dan mengembangkan teknologi di masa depan, diperlukan penguasaan dan kepemilikan matematika yang kuat semenjak dini (Permendikbud No.58 Tahun 2014). Maka dari itu, pelajaran matematika penting untuk diajarkan kepada seluruh generasi penerus bangsa.

National Council of Teachers of Mathematics atau NCTM (Fauziah, 2010)menyatakan standar matematika sekolah terdiri atas standar isi dan proses. Standar proses terdiri atas penalaran, pemecahan masalah, pembuktian, keterkaitan, repsresentasi dan komunikasi. Salah satu aktivitas matematika yang banyak hubungannya dengan sifat matematika adalah kemampuan pemecahan masalah. Menurut Branca (Herman Tatang, 2007)pentingnya kepemilikan pemecahan masalah dalam belajar matematika," a) kemampuan penyelesaian masalah ialah tujuan umum pembelajaran matematika, dan juga sebagai jantung dari matematika; b) penyelesaian masalah merupakan prosedur, metode dan strategi pemecahan masalah dan; c) pemecahan masalah merupakan kemampuan dasar matematika". Hal ini pula dikemukakan Susilawati (Herman Tatang, 2007)"pemecahan masalah ialah salah satu pendekatan dan pula sebagai tujuan dalam pembelajaran matematika".Pendapat Branca dan Susilawati menunjukkan bahwa pemecahan masalah ialah dasar pengajaran matematika yang dan merupakan tujuan umum matematika.Matematika merupakan pelajaran yang sulit, hal ini diungkapkan oleh siswa dalam kegiatan wawancara peneliti.Sejalan dengan itu hal ini ditunjukan oleh sebuah hasil penelitian internasional dalam bidang sains dan matematika Programe for Internasional Student Assesment (PISA) tahun 2012 (Eftafiyana, Nurjanah, Armania, Sugandi, \& Fitriani, 2018)negara Indonesia menduduki peringkat 64 dari 65 negara.Serta laporan TIMMS tahun 1999 (Fauziah, 2010)menunjukkan kemampuan siswa SMP dalam pembelajaran matematika lebih baik menyelesaikan permasalahan tentang prosedur dan fakta, tetapi sangat lemah ketika memecahkan permasalahan yang tidak rutin yang ada kaitannya dengan jastifikasi atau pembuktian.Adapun pengertian kemampuan pemecahan masalah menurut (Sugandi, 2014) kemampuan pemecahan masalah ialah salah satu hasil belajar yang dicapai, dan juga sangat penting bagi siswa.

Pengertian pemecahan masalah sebagai proses mengacu pada kegiatan yang lebih mengutamakan pentingnya strategi,heuristic dan langkah-langkah dalam menyelesaikan permasalahan, sehingga siswa dapat menemukan penyelesaian dan bukan hanya pada jawaban itu sendiri. Proses pemecahan masalah matematik berbeda dengan proses menyelesaikan soal matematika, jika suatu soal matematika dapat segera ditemukan cara menyelesaikannya, maka soal tersebut tergolong pada soal rutin dan bukan merupakan suatu masalah. Karena menyelesaikan masalah bagi siswa itu dapat bermakna proses untuk menerima tantangan, sebagaimana dikatakan Hudoyo(Hidayat \& Sariningsih, 2018). Dipandang dari jenis belajarnya, kemampuan penyelesaian masalah tergolong pada kemampuan tingkat tinggi yang antara lain memerlukan dalam kemampuan jenis belajar yang lebih rendah dan pemahaman prasyaratnya. Sejalan dengan pendapat Gagne (Ruseffendi, 2006) bahwa pemecahan masalah ialah kemampuan paling tinggi dan lebih kompleks.Pemecahan masalah tidak sekedar mengaplikasikan suatu algoritma, namun memuat pemahaman dan aktivitas intelektual dan bukan berupa kegiatan rutin.Hasil penelitian di kelas VII MTs, kualitas pembelajaran di sekolah yang diteliti masih tergolong rendah, hal itu terjadi karena kurangnya pembelajaran 
yang diawali dengan suatu permasalahan nyata dan siswapun kurang diarahkan untuk menyelesaikan soal atau masalah melalui penyelidikan.

Kondisi belajar yang kurang optimal dalam penyampaian materi serta pemakaian media pembelajaran yang sangat minim dan kurang menarik, sehingga menyebabkan siswa tidak tertarik dan sibuk sendiri dengan kegiatan lainnya serta belum adanya pembelajaran yang dilakukan secara berkelompok. Pada saat proses pembelajaran berlangsung, kegiatan dalam pembelajaran lebih terfokus kepada guru dari mulai pembahasan sampai menyimpulkan. Hal ini menyebabkan siswa minim partisipasi dalam proses pembelajaran, selain itu memberikan motivasi dari guru kepada siswa masih minim. Salah satu faktor tersebut menyebabkan hasil penilaian masih dibawah KKM (70) yang membuktikan bahwa kualitas belajar mengajar matematika di kelas VII MTs masih rendah, karena komponen-komponen pembelajarannya tidak mendukung secara maksimal.Untuk itu, usaha meningkatkan belajar mengajar pembelajaran matematika yaitu dengan menggunakan pendekatan Problem Based Learning.Dalam penggunaan Problem Based Learning dalam pembelajaran matematika digunakan masalah sebagai kendaraan untuk meningkatkan kemampuan pemecahan masalah, topik pembahasan, dan pengaturan diri.Dan juga membuat siswa lebih bertanggung jawab dalam mengelola pembelajaran sendiri, sehingga manfaat yang mereka dapat lebih banyak dan mereka bisa menyalurkan serta menambah kemampuannya seperti kemampuan berkomunikasi, kerjasama tim serta memecahkan masalah, sehingga siswa dapat memahami konsep atau materi yang dipelajari. Adapun, salah satu tujuan dari mata pelajaran matematika adalah agar peserta didik memiliki kemampuan dalam memecahkan masalah.

Problem Based Learning adalah pendekatan mengajar dengan menggunakan permasalahan sebagai pusat untuk menumbuh-kembangkan kemampuan pemecahan masalah, pengaturan diri dan materi (Eggen \& Kauchak, 2012). (Supinah \& Sutanti, 2010)mengemukakan bahwa Problem Based Learning sebagai pendekatan pembelajaran yang diawali dengan memberikan permasalahan diawal pembelajaran dan permasalahan tersebut yang pernah dialami oleh siswa.Selanjutnya siswa menyelesaikan masalah tersebut untuk menemukan pengetahuan baru.Kracjik \& Blumenfeld (Eggen \& Kauchak, 2012)mengatakan bahwa kegiatan Problem Based Learning bermula dari satu masalah dan memecahkannya adalah fokus dalam pembelajarannya.Langkah awal dari pembelajaran berdasar masalah adalah mengajukan masalah, selanjutnya berdasarkan dari masalah tersebut akan ditemukan konsep, prinsip serta aturan-aturan. Masalah yang diajukan secara autentik ditujukan dengan memacu pada kehidupan riil.Berdasarkan uraian yang telah dipaparkan, terdapat masalah yang cukup menarik untuk diteliti.Sehingga peneliti ingin menerapkan antara kemampuan pemecahan masalah matematis siswa SMP yang menggunakan pendekatan problem based learning.

\section{METODE}

Metode penelitian ini Penelitian Tindakan Kelas (PTK) yaitu penelitian untuk memberikan gambaran mengenai tindakan dan strategi pembelajaran yang tepat untuk meningkatkan kemampuan guru matematik siswa dan interaktif siswa dalam belajar.Waktu pada penelitian inidimulai dari hari rabu, 08 November sampai dengan tanggal 22 November 2017 pada semester ganjil tahun akademik 2017/2018 di MTs Muslimin Tanjungwangi. Adapun subjek penelitian pada penelitian ini adalah kelas VII-B dengan jumlah 30 orang yang terdiri atas 12 siswa laki-laki dan 18 siswa perempuan. 


\section{HASIL DAN PEMBAHASAN}

\section{Hasil}

\section{Pembahasan Kegiatan Siklus I}

Tahap pertama, ialah perencanaan.Guru membuat Lembar Kerja Siswa (LKS) dan mempersiapkan apa yang dibutuhkan pada saat pembelajaran. Kegiatan siklus 1 membahas mengenai materi prasyarat dan membahas materi perbandingan dan skala memakai pendekatan problem based learningdan dilaksanakan skenario pembelajaran pertemuan pertama. Pelaksanaan lainnya yaitu lebih memantapkan pengetahuan dan pemahaman mengenai pelaksanaan pembelajaran. Tahap kedua ialah pelaksaan tindakan.Pelaksanaan tindakan dilakukan guru matematika kelas VII-B MTs Muslimin Tanjungwangi, sedangkan peneliti bertindak sebagai guru yang mengajar.Tindakan siklus I dilaksanakan 2 kali pertemuan.

Selanjutnya disajikan pembelajaran kelas pertama (pertemuan pertama). Penyajian kelas pertama pada siklus I yaitu pada hari Rabu, 8 November 2017 dengan materi "konsep perbandingan dan skala".RPP yang dipersiapkan adalah pendekatan problem based learningdengan metode ekspositori dan diskusi. Pembelajaran dimulai pada saat guru mengucapkan salam dan mengabsen kehadiran siswa. Selanjutnya guru memberikan motivasi kepada siswa dengan menjelaskan pentingnya mempelajari konsep perbandingan dan skala dalam kehidupan.Guru menyajikan apersepsi yaitu mengaitkan konsep awal yang dimiliki siswa dengan materi pokok pelajaran. Apersepsi ini juga dimaksudkan untuk mengingatkan dan mengulang kembali pengetahuan yang dimiliki siswa mengenai konsep perbandingan dan skala.Dengan demikian mengawali kegiatan inti, guru memulai materi dengan meminta siswa untuk memberikan contoh perbandingan dan skala pada suatu benda. Guru memberikan stimulus untuk siswa agar aktif memberikan contoh-contoh perbandingan dan skala pada suatu benda. Selanjutnya guru bertanya mengenai perbandingan dan skala pada suatu benda dan siswa antusias menjawab. Sebagian besar siswa lupa jika ditanya mengenai bagaimana cara menghitung perbandingan dan skala. Guru memberikan apresiasi atas keberanian siswanya dengan memberikan bintang atau nilai tambahan. Kemudian guru memberikan masalah kepada siswa serta dibimbing.

Penyajian kelas kedua (pertemuan kedua).Penyajian kelas kedua dilaksanakan pada hari Rabu, 15 November 2017 dengan materi yang samamengenai "perbandingan dan skala". RPP yang dipersiapkan adalah pendekatan problem based learning dengan ekspositori dan diskusi. Guru mengawali pembelajaran dengan pembukaan dilanjutkan dengan mengucapkan salam dan sedikit bercerita tentang pencapaian pembelajaran yang akan dicapai pada pertemuan kedua. Selanjutnya guru memberikan motivasi kepada siswa dengan menjelaskan pentingnya mempelajari konsep perbandingan dan skala dalam kehidupan sehari-hari. Guru melakukan apersepsi yaitu sedikit mengulang materi sebelumnya.

Dengan demikian mengawali kegiatan inti. Guru memulai materi dengan siswa mengamati LKS yang memberi masalah kepada siswa. Setiap kelompok berdiskusi. Selanjutnya jika ada satu orang dari kelompok bertanya ke kelompok lain guru mempersilahkan dan siswa tersebut mendapat point. Guru memberikan apresiasi atas keberanian siswanya dengan ungkapan. Bagus! Yuk kita bahas bersama-sama. Kemudian bersama-sama menyimpulkan apa yang dipelajari.

Tahap ketiga, yaitu evaluasi.Pada setiap pertemuan, pengamatan dilakukan awal sampai akhir pembelajaran.Setelah 2 kali pertemuan untuk menyelesaikan kompetensi dasar menggunakan 
operasi aljabar untuk menentukan penerapan rumus perbandingan dan skalayang merupakan penjabaran dari standar kompetensi menggunakan operasialjabar dalam pemecahan masalah, dilaksanakan evaluasi pada Rabu, 15 November 2017. Adanya evaluasi untuk mengetahui sampai mana penguasaan siswa mengenai konsep perbandingan dan skalapada materi perbandingan dan skala dengan menggunakan pendekatan problem based learning, hasil tes menunjukkan siswa banyak yang kebingungan mengenai konsep matematika. Dilihat dari tes ini, perlu ada penambahan tindakan agar siswa betul mengerti mengenai apa yang dipelajari. Dilihat dari skor siswa yang diperoleh terdiri atas d soal-soal pada tes dari siklus I ini, diperoleh ketuntasan mencapai 45\%. Hal ini menunjukkan penguasaan berfikir siswa mengenai konsep matematika kurang. Namun demikian terdapat 7 siswa diantaranya mencapai nilai diatas 60. Selain itu, hasil tes siklus I juga penting untuk melihat kemampuan siswa dalam penguasaan konsep matematika. Tujuan hal ini untuk mengetahui hasil untuk setiap pertemuan.

Tahap keempat, ialah refleksi dengan guru menilai pembelajaran dari pelaksanaan siklus I. Pada siklus I penerapan pendekatan masih belum maksimal, karena pendekatan pembelajaran ini baru pertama kali diterapkan di kelas VII MTs i. Rata-rata ketuntasan pada siklus I hanya mencapai 45\%. Kelemahan tersebut antara lain: (1) Tidak semua siswa aktif dalam pembelajaran, (2) Guru kurang persiapan dalam pelaksanaan pembelajaran. (3) Siswa masih melihat atau mengikuti alur pada soal-soal sebelumnya, ketika diberi soal yang sedikit berbeda siswa merasa kebingungan, (4) Siswa sedikit mengemukakan pendapat dan tidak berani mengemukakan kesulitanya dalam menyusun soal, (5) Siswa tidak berani memprediksi soal yang lebih rumit dari soal yang sudah diberikan sebelumnya berdasarkan pembelajaran yang diajarkan.Selain itu, banyak siswa yang tidak fokus dalam pembelajaran, tidak berani mengemukakan kesulitannya dalam membuat soal dan masih sedikit siswa yang mampu menyampaikan pendapatnya dalam diskusi kelas.Siswa tidak mengembangkan ide kreatifnya dalam menyusun soal.

Tabel 1. Data Hasil Observasi Keterampilan Guru Siklus I

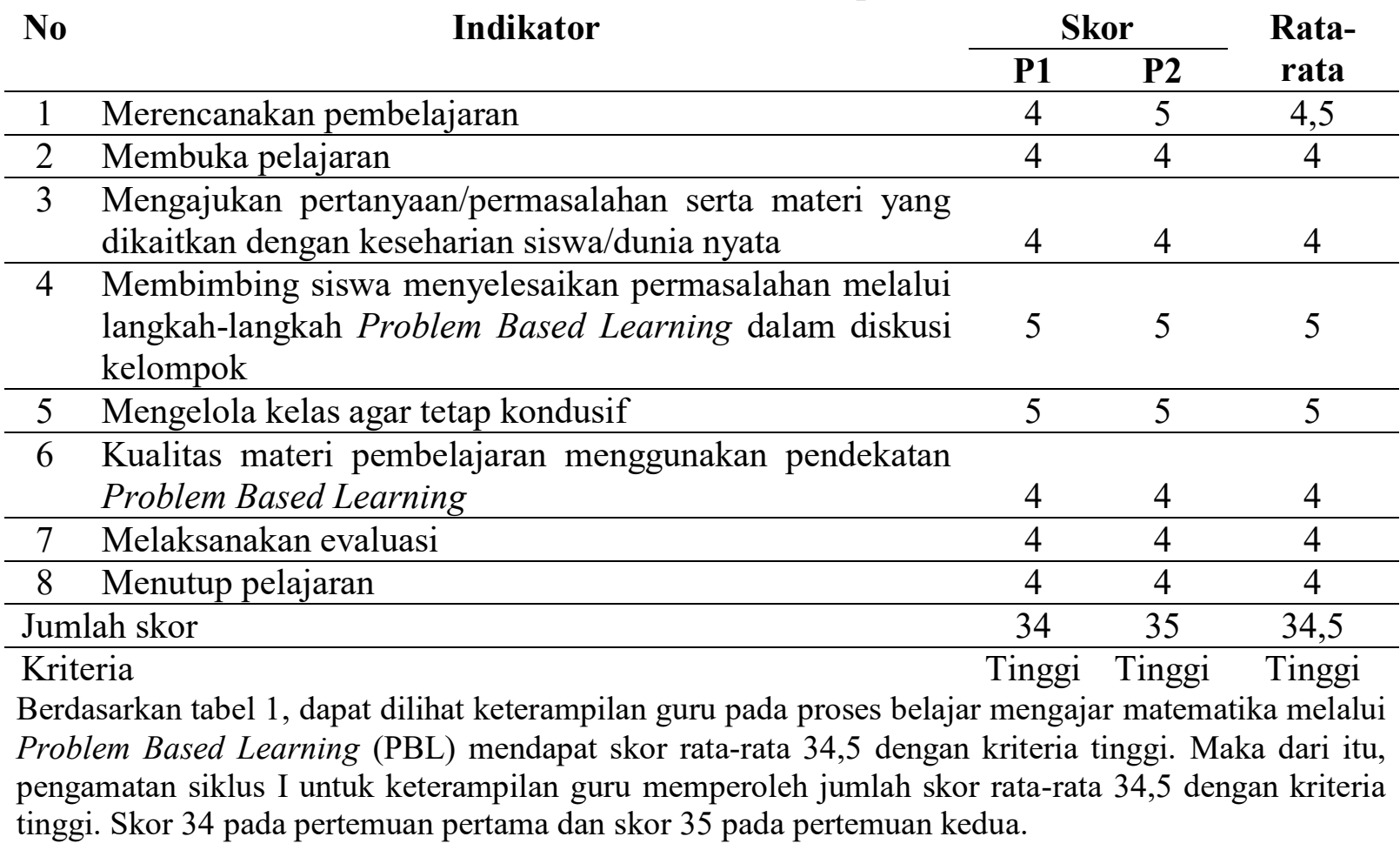


Dilihat dari data penelitian pada siklus I mengenai hasil belajar matematika melalui Problem Based Learning (PBL) pembelajaran diperoleh data seperti pada tabel berikut:

Tabel 2. Frekuensi Ketuntasan Klasikal Hasil Belajar Siklus I
\begin{tabular}{|llcc} 
No & Keterangan & P I & P II \\
\hline 1 & Nilai Rata-rata Kelas & 56,8 & 61,9 \\
\hline 2 & Nilai Tertinggi & 100 & 100 \\
\hline 3 & Nilai Terendah & 0 & 0 \\
\hline 4 & Siswa Tuntas Belajar & 16 & 17 \\
\hline 5 & Siswa Tidak Tuntas Belajar & 14 & 13 \\
\hline 6 & Persentase Ketuntasan Belajar & $62 \%$ & $66,9 \%$
\end{tabular}

Berdasarkan tabel 2 nilai rata-rata pertemuan pertama adalah 56,8 dengan nilai terendah 0 , nilai tertinggi 100. Jumlah siswa yang mendapatkan nilai tuntas sebanyak 16 siswa, dansiswa yang tidak tuntas sebanyak 14 siswa, sehingga diperoleh ketuntasan belajar siswa sebesar 62 $\%$ dan nilai rata-rata pada pertemuan kedua adalah 61,9 dengan nilai terendah 0 , nilai tertinggi 100. Siswa yang memperoleh nilai tuntas sebanyak 17 siswa, sedangkan yang tidak tuntas sebanyak 13 siswa, sehingga diperoleh ketuntasan belajar siswa sebesar $66,9 \%$.

\section{Hasil Tindakan Siklus II}

Kegiatan yang dilakukan tahap perencanaan di siklus II sama dengan kegiatan perencanaan yang ada di siklus I, hanya ada tambahan kegiatan di siklus II yaitu RPP yang dibuat terdiri dari 2 pertemuan pada lanjutan materi perbandingan dan skala, kemudian berdasarkan RPP siklus II ini dilakukan dengan metode ceramah, tanya jawab dan diskusi kelompok. Kegiatan selanjutnya yaitu mewawancarai guru matematika dan sebagian siswa untuk mengetahui pendapat mereka selama proses pembelajaran yang sudah dilakukan.

Pelaksanaan kegiatan/tindakan pada siklus II terdiri dari 2 pertemuan. Guru bertindak sebagai pengajar dan juga sebagai pengamat. Adapun penyajian kelas pertama (pertemuan pertama) dilaksanakan hari Rabu, 15 November 2017 dengan materi "perbandingan dan skala". Sebagai gambaranproses pembelajaran diawali pembukaan yang dilakukan guru dengan mengucapkan salam, menyampaikan tujuan pembelajaran, memberi stimulus kepada siswa tentang pentingnya materi ini dalam kehidupan.Selanjutnya, guru membagi siswa kedalam 5 kelompok. Penyusunan kelompok dibagi rata, danterdiri atas siswa dengan berkemampuan homogen. Pada kegiatan inti ini, selanjutnya siswa diberikan LKS perbandingan dan skala. Guru memastikan setiap kelompok untuk mendiskusikan kemungkinan penyelesaian yang benar dan carapenyelesaiannya. Tugas paling penting pada pembelajaran ini ialah memastikan dan memantau kerja setiap kelompok serta membimbing kelompok yang mengalami kesulitan.Kesempatan ini kurang dimanfaatkan siswa untuk bertanya.Pada setiap kelompok kemudian guru memberikan LKS dan diberikan masalah. Guru memastikan setiap kelompok mendiskusikan kemungkinan jawaban yang akan diperoleh. Langkah terakhir dalam kegiatan inti adalah meminta siswa dalam kelompoknya untuk memprediksikan kemungkinan soal yang lebih sulit.Beberapa menit kemudian, guru mempersilahkan kelompok untuk presentasi hasil diskusinya.

Penyajian kelas kedua, dilaksanakan pada hari Rabu, 22 November 2017.Pertemuan terakhir mengenai materi perbandingan dan skala.Proses belajar mengajarnya diawali seperti halnya kegiatan-kegiatan sebelumnya.Setelah 2 kali pertemuan untuk menyelesaikan kompetensi dasar menggunakan materi prasyarat yang menunjang materi perbandingan dan skala 
pemecahan masalah, dilaksanakan evaluasi pada Rabu, 22 November 2017.Dilihat dari tes menunjukkan bahwa ada peningkatan pembelajaran jika dibandingkan dengan siklus I. Hasil tes ini menunjukkan penguasaan siswa secara klasikal terhadap materi pembelajaran sudah cukup baik.Dengan melihat skor yang diperoleh siswa dari soal-soal yang diberikan pada tes siklus II ini, diperoleh ketuntasan mencapai 60\%. Hal ini menunjukkan penguasaan konsep matematika sudah ada peningkatan. Namun demikian terdapat siswa diantaranya mencapai nilai diatas 65 . Hal ini bertujuan untuk mengetahui hasil pembelajaran dengan menggunakan pendekatan problem based learning untuk setiap pertemuan.Pada tahap refleksi, guru menilai pembelajaran dari pelaksanaan siklus II. Pada siklus II adanya peningkatan pada penerapan pendekatan. Rata-rata ketuntasan pembelajaran pada siklus II hanya mencapai 60\%.

Tabel 3 Data Hasil Observasi Keterampilan Guru Siklus II

\begin{tabular}{|c|c|c|c|c|}
\hline \multirow[t]{2}{*}{ No } & \multirow[t]{2}{*}{ Indikator } & \multicolumn{2}{|c|}{ Skor } & \multirow{2}{*}{$\begin{array}{l}\text { Rata- } \\
\text { rata }\end{array}$} \\
\hline & & p.I & p.II & \\
\hline 1 & Merencanakan pembelajaran & 5 & 5 & 5 \\
\hline 2 & Membuka pelajaran & 5 & 5 & 5 \\
\hline 3 & $\begin{array}{l}\text { Mengajukan pertanyaan/permasalahan serta materi } \\
\text { yang dikaitkan dengan keseharian siswa/dunia nyata }\end{array}$ & 5 & 5 & 5 \\
\hline 4 & $\begin{array}{l}\text { Membimbing siswa menyelesaikan permasalahan } \\
\text { melalui langkah-langkah Problem Based Learning } \\
\text { dalam diskusi kelompok }\end{array}$ & 5 & 5 & 5 \\
\hline 5 & Mengelola kelas agar tetap kondusif & 4 & 5 & 4,5 \\
\hline 6 & $\begin{array}{lcc}\text { Kualitas materi } & \text { pembelajaran } & \text { menggunakan } \\
\text { pendekatan } & \text { Problem } & \text { Based Learning }\end{array}$ & 4 & 5 & 4,5 \\
\hline 7 & Melaksanakan evaluasi & 5 & 5 & 5 \\
\hline 8 & Menutup pelajaran & 5 & 5 & 5 \\
\hline Jum & ah skor & 38 & 40 & 39 \\
\hline Krit & & $\begin{array}{l}\text { Sangat } \\
\text { Tinggi }\end{array}$ & $\begin{array}{l}\text { Sangat } \\
\text { Tinggi }\end{array}$ & $\begin{array}{l}\text { Sangat } \\
\text { Tinggi }\end{array}$ \\
\hline
\end{tabular}

Berdasarkan tabel 3, dapat dilihat bahwa keterampilan guru pembelajaran matematika melalui Problem Based Learning (PBL) memperoleh skor rata-rata 39 dengan kriteria sangat tinggi.Berdasarkan uraian dapat disimpulkan dalam pengamatan keterampilan guru pada siklus II memperoleh jumlah skor rata-rata 39 dengan kriteria sangat tinggi.Skor 38 pada pertemuan pertama, sedangkan skor 40 pada pertemuan kedua.

Berdasarkan data hasil penelitian pada siklus II pertemuan pertama dan kedua mengenai hasil belajar matematika melalui Problem Based Learning (PBL) diperoleh data seperti pada tabel berikut:

Tabel 4 Frekuensi Ketuntasan Klasikal Hasil Belajar Siklus II
\begin{tabular}{|llcc} 
No & Keterangan & P I & P II \\
\hline 1 & Nilai Rata-rata Kelas & 82,8 & 85,7 \\
\hline 2 & Nilai Tertinggi & 100 & 100 \\
\hline 3 & Nilai Terendah & 15 & 35 \\
\hline 4 & Siswa Tuntas Belajar & 24 & 26 \\
\hline 5 & Siswa Tidak Tuntas Belajar & 6 & 4 \\
\hline 6 & Persentase Ketuntasan Belajar & $75 \%$ & $82 \%$
\end{tabular}

Berdasarkan tabel 4 pada siklus II nilai rata-rata pertemuan pertama adalah 82,8dengan nilai terendah 15, nilai tertinggi 100.Siswa dengan nilai tuntas sebanyak 24 siswa dan siswa yang 
tidak tuntas sebanyak 6 siswa sehingga diperoleh ketuntasan belajar siswa sebesar $75 \%$. Setelah dilakukan tindakan pada siklus II pertemuan 2, nilai rata-rata pada pertemuan kedua adalah 85,7 dengan nilai terendah 35, nilai tertinggi 100 . Siswa dengan nilai tuntas sebanyak 26 siswa, sedangkan yang tidak tuntas 4 siswa, dan diperoleh ketuntasan belajar siswa sebesar $82 \%$.

\section{Pembahasan}

Penelitian tindakan kelas ini terdiri atas 2 siklus. Setiap siklus terdiri atas 2 pertemuan yang dilaksanakan dengan prosedur penelitian.Materi yang diambil disesuaikan dengan materi pembelajaran di sekolah.Hasil observasi keterampilan guru terlihat meningkatnya keterampilan guru.Hal ini terbukti bahwa siklus I mendapat jumlah skor rata-rata 34,5 dengan kriteria tinggi dan juga peningkatan di siklus II dengan jumlah skor rata-rata 39 dengan kriteria sangat tinggi. Peningkatan aktivitas siswa mendapat jumlah skor 16,05 pada siklus I dengan kriteria tinggi dan ada peningkatan pada siklus II dengan jumlah skor 20,4 dengan kriteria sangat tinggi.

Hasil belajar kognitif siklus I pertemuan pertama nilai rata-ratanya 56,8 dengan nilai tertinggi 100 dan nilai terendah 0 . Pada siklus I pertemuan kedua nilai rata-ratanya 61,9 dengan nilai tertinggi 100 dan nilai terendah 0.Terlihat adanya peningkatan dari siklus I pertemuan pertama ke pertemuan kedua karena siswa sudah mulai dapat menguasai materi. Selain itu siswa juga sudah terlihat aktif berdiskusi dengan teman sekelompoknya untuk memecahkan permasalahan yang diberikan guru. Setelah melaksanakan tindakan siklus I, guru melakukan refleksi dan revisi untuk diterapkan pada siklus II.Salah satu revisi atau perbaikan yang dilakukan yaitu guru bisa mengaitkan materi pecahan dalam perbandingan dan skala dengan materi sebelumnya seperti perkalian dan pembagian pecahan, konversi satuan panjang, serta waktu.Hal ini mengakibatkan pertemuan pertama pada siklus II, terjadi peningkatan lagi.Pada siklus II, pertemuan pertama nilai rata-ratanya 82,8 dengan nilai terendah 100 dan nilai terendah 15.Setelah melaksanakan tindakan pada siklus II pertemuan kedua adanya peningkatan dari hasil belajar siswa.Hal ini terlihat pada nilai rata-ratanya yaitu 85,7 dengan nilai tertinggi 100 dan nilai terendah 35. Persentase ketuntasan klasikal meningkat dari siklus I pertemuan 1 sebesar $62 \%$ dan pertemuan 2 sebesar $66,9 \%$. Selanjutnya pada siklus II juga mengalami peningkatan, pada pertemuan pertama $75 \%$ menjadi $82 \%$. Berarti yang telah mencapai lebih dari atau sama dengan KKM yang ditentukan yaitu 70. Diakhir siklus I hasil belajar siswa terlihat bahwa diakhir siklus I persentase ketuntasan belajar sebesar $66,9 \%$ dan belum memenuhi kriteria ketuntasan belajar klasikal yang telah ditentukan, maka penelitian dilanjukan ke siklus II.Setelah pelaksanaan siklus II, menunjukkan bahwa diakhir pembelajaran pada siklus II persentase ketuntasan belajar mencapai $82 \%$ dengan banyaknya siswa yang tuntas sebanyak 26 siswa, berarti ketuntasan berdasarkan jumlah siswa saat itu yaitu 30 orang, karena ada 4 orang yang belum tuntas. Karena pada siklus II telah mencapai KKM, maka penelitian tidak dilanjutkan ke siklus berikutnya.

\section{KESIMPULAN}

Berdasarkan hasil analisis dan pembahasan, maka disimpulkan bahwa pendekatan Problem Based Learning dapat meningkatkan kemampuan pemecahan masalah pada materi skala dan perbandingan. 


\section{DAFTAR PUSTAKA}

Eftafiyana, S., Nurjanah, S. A., Armania, M., Sugandi, A. I., \& Fitriani, N. (2018). Hubungan Antara Kemampuan Berpikir Kreatif Matematis dan Motivasi Belajar Siswa SMP yang Menggunakan Pendekatan Creative Problem Solving, 2(2), 85-92.

Eggen, P., \& Kauchak, D. (2012). Strategi dan Model Pembelajaran Mengajarkan Konten dan Keterampilan Berpikir. Jakarta: Indeks.

Fauziah, A. (2010). Peningkatan Kemampuan Pemahaman Dan Pemecahan Masalah Matematik Siswa Smp Melalui Strategi React. Forum Kependidikan, 30(1994), 1-13.

Herman Tatang. (2007). Pembelajaran Berbasis Masalah untuk Meningkatkan Kemampuan Berpikir Matematis Tingkat Tinggi Siswa Sekolah Menengah Pertama. Educationist, 1(1), 3. Retrieved from http://ejournal.sps.upi.edu/index.php/educationist/article/view/28/22

Hidayat, W., \& Sariningsih, R. (2018). Kemampuan Pemecahan Masalah Matematis Dan Adversity Quotient Siswa SMP Melaluo Pembelajaran Open Ended, 2(1), 109-118.

Ruseffendi, E. T. (2006). Pengantar Kepada Membantu Guru Mengembangkan Kompetensinya dalam Pengajaran Matematika untuk Meningkatkan CBSA. Bandung: Tarsito.

Setiawan, W. (2015). Pencapaian Kemampuan Pemahaman dan Koneksi Matematis Siswa SMP dengan Model Pembelajaran Connecting Organizing Reflecting and Extending. In Seminar Nasional Matematika dan Pendidikan Matematika. Cimahi: STKIP Siliwangi. Retrieved from http://publikasi.stkipsiliwangi.ac.id/prosiding/prosiding-seminarnasional-matematika-dan-pendidikan-matematika-tahun-2015/

Sugandi, A. I. (2014). Pendekatan Kontekstual Sebagai Pendekatan dalam Pembelajatran yang Humanis untuk Meningkatkan Kemampuan Berfikir Matematis Tingkat Tinggi. In Prosiding Seminar Nasional Pendidikan Matematika (Vol. 1, pp. 152-156). Cimahi.

Supinah, \& Sutanti, T. (2010). Pembelajaran Berbasis Masalah Matematika di SD. Yogyakarta: PPPPTK Matematika. 
122 Marlina,Nurjahidah, Sugandi \& Setiawan, Penerapan Pendekatan Problem Based ... 